\title{
Economic Evaluation of Supported-Employment Inspired Program for Pupils With Intellectual Disabilities
}

\section{Susanna Larsson Tholén}

PhD, Researcher, The Swedish Institute for Disability Research, Örebro University, Sweden

I Lars Hultkrantz'

PhD, Professor, School of Business, Örebro University, Sweden

I Mattias Persson

PhD, Researcher, School of Business, Örebro University, Sweden

\begin{abstract}
In this study, we investigate whether, or to what degree, a 'business case' could be made for implementation of a Supported-Employment (SE) inspired program for pupils with intellectual disabilities (IDs), starting during the final school years. For this aim, we do a quasi-experimental before-after intervention impact evaluation of such a project funded by the European Social Fund in the Swedish city of Örebro (I 35,000 inhabitants) during 20 I 0-20 I 3. From an estimate of the average treatment effect, we calculate the internal net present value and the payback period that would make this program break even from avoided expenditure for day-activity services, assuming that it had been funded entirely by the municipality.
\end{abstract}

\section{KEY WORDS}

Intellectual disability / social investments / special school / transition / working life

DOI

10.1829|/njwls.v7il.81401

\section{Introduction}

hile the UN Convention of the rights of persons with disabilities recognizes the right to work on an equal basis with others persons, job opportunities are often missing for people with intellectual disability (ID). ${ }^{1}$ There is ample evidence that there are effective remedies, in particular so-called Supported-Employment (SE) strategies (see Marshall et al., 2014, for a review). However, these programs are considered costly (as will be evidenced in the description of our study case). Even if a measure is proven to be efficient in a societal and long-term perspective, it may still be found too expensive to be given priority by a local government administration that has to balance its yearly budget.

Sub-optimization in public administration can arise from myopia and silo mentality in conventional budget planning, which possibly also hampers innovation (Hope \&

\footnotetext{
${ }^{1}$ Lars Hultkrantz, School of Business, Örebro University, SE-701 82 Örebro, Sweden.

E-mail: lars.hultkrantz@oru.se.
} 
Fraser, 1997, 2003). A specific concern that relates to local government operations such as administration of education and social services is sub-optimization in the allocation of resources for prevention and early intervention policies for children and youth. Spending for such purposes can be seen as investment in human capital expected to yield individual and social benefits. However, these benefits evolve over the lifespan of the individuals. Also, the decision to allocate resources may be the responsibility of a specific division that possibly ignores effects that are external to its own budget.

In this study, we investigate whether, or to what degree, a 'business case' could be made for implementation of a SE-inspired program starting during the last school years, targeting youth with ID before, during and after transition to employment. For this aim, we do a quasi-experimental before-after intervention impact evaluation of a project funded by the European Social Fund in the Swedish city of Örebro $(135,000$ inhabitants) during 2010-2013. From an estimate of the average treatment effect, we calculate the internal net present value and the payback period that would make this program break even from avoided expenditure for day-activity services, assuming that it had been funded entirely by the municipality (or its social investment fund).

The next section gives some background on SE and the literature on impact and economic evaluation of such programs. Section 3 presents the study case, 'Job in Sight', and section 4 describes methods and data. Section 5 presents results, first from simple comparisons of outcomes between the intervention and control groups, then from the Probit model analysis, and finally the economic assessments. Discussion and conclusions follow in the end.

\section{Background}

In a recent review of the labor market situation of people with disabilities in the European Union, Greve (2009) observes that persons with disabilities generally '...experience considerable difficulties in entering and remaining in the labor market' (p. 11) and that these problems are especially large for persons with ID.

From an employer's point of view, the productivity of a young person without a previous employment history is an experience good (Tirole, 1988, ch. 5), that is, it is not revealed until after the decision to employ is made. As the degree of and nature of ID can vary substantially from person to person, this may give rise to statistical discrimination, that is, employers avert from hiring on a categorical instead of individual basis. On the supply side, that is, from the prospective employee's point of view, there can be similar concerns related to features that can only be learned from experience, for instance as to whether a specific employment opportunity would pose insurmountable intellectual, social, or practical challenges to the individual. ${ }^{2}$

As a response to such labor market matching issues for persons with ID, SE strategies were developed during the 1980s in the United States. A SE strategy aims at a competitive employment for individuals with disabilities using an empowerment approach (Germundsson et al., 2012).

The basic concept of SE is that all people have abilities and skills, and how these develop depends largely on facilitating or hindering factors in the work-place environment. The aim of SE is to find and adapt workplace environments so that the talents of the individual person can be made justice (Wehman et al., 2007). SE has been spread 
worldwide and is today used in various cultural environments (de Urríes et al., 2005; King et al., 2006; Mak et al., 2006) and for people with various disabilities (Blitz \& Mechanic, 2006; Bond et al., 2008; Rose et al., 2005) as well as persons who otherwise are outside the labor market (Drake \& Bond, 2008). SE was initially developed for people with ID, but during the years, the target audience has expanded to include, for example, people with mental disabilities. The method has therefore developed from being a job program to also include rehabilitative efforts (Antonson 2003) as there are somewhat different cognitive and psychiatric problems, in the various disability groups. Two recent review articles, Marshall et al. (2014) and Dowler and Walls (2014), conclude that 'participants receiving supported employment had significantly higher rates of competitive employment' (Marshall et al., 2014, p. 18). However, Marshall et al. (2014) further observe that SE is designed for adults so their review excluded studies of adolescents. In fact, studies on youth yield mixed evidence. Burke-Miller et al. (2012) in a study of SE programs for people with severe mental illnesses found that the main effect in their study (mean proportion who worked at all) was smaller in the treatment group than in the comparison group for 'transition age youth', defined as ages 18-24, while there were positive differences for young adults (ages 25-30) and older ages. A possible explanation is that the SE programs focused on staying at jobs when the youth may 'prefer to change jobs as a means of career exploration and identity development' (p. 176). Another study (Cimera, 2010b) among young adults in the US compared outcomes across groups of individuals receiving no transition services, receiving transition services in school or receiving community-based transition services when they were in high school. It was found that only individuals who received services in the community were employed significantly longer than their peers with no transition services.

A multitude of economic evaluations of SE programs, comparing these to regular vocational training programs etc., has been conducted in the U.S. (Cimera, 1998, 2010a, 2012; Clark et al., 1998; Conley et al., 1989; Hill \& Wehman, 1983; Hill et al., 1987; Latimer, 2001; Rogers et al., 1995). An early European such study, for Wales, is the one by Beyer and Kilsby (1998). Knapp et al. (2013) analyzed a SE program for 312 individuals with severe mental illness conducted in six European cities across the continent. Compared to a regular vocational program, the SE was found to be more cost-effective in five out of six cities to generate more days in employment. Similar results were held for SE programs for individuals with severe mental illnesses or autism compared with a regular vocational program in the cities of Bern (Hoffmann et al., 2014) and London (Heslin et al., 2011; Mavranezouli et al., 2014). Reme et al. (2015) evaluate a program integrating cognitive-behavioral therapy (CBT) and SE in Norway focusing on effects on work participation of individuals with common mental disorders. The program was effective. Work participation increased overall and especially for recipients with long periods of social benefits. However, costs exceeded the present value of benefits. This conclusion would have been different though if the program had been limited to only long-term recipients of social benefits.

The Washington State Institute for Public Policy (WSIPP) regularly makes and updates benefit-cost assessments of various prevention and early interventions programs based on calculated effect sizes for the state of Washington derived from meta-analysis of impact studies. The most recent update (WSIPP 2015) of the benefit-cost estimates for the SE for individuals with serious mental illness sets benefits at about $\$ 1,400$ per participant, compared with a cost of $\$ 792$, with a benefit-cost ratio (BCR) of 1.8 . 
SE was first implemented in Sweden in the 1990s. In 1993, the Swedish Public Employment Service, inspired by the SE strategy, started the program Special Introductory and Follow-up Support (Gustafsson, 2014). This program is today established within the Swedish social and labor market policies (Gustafsson, 2014). A literature review that focused on the situation of young people with reduced work capacity found that variants of the SE strategy are widely used in Sweden, but there is a lack of structured follow-ups and projects design that make it possible to observe effects (Westerholm et al., 2013). As an example, Socialstyrelsen (2013) made a follow-up type of evaluation of a 2-year trial in 30 municipalities of the SE, without any control group. As argued by Gustafsson et al. (2015), one might expect different results in Sweden, where the main policy for creating job opportunities is based on carrots (wage subsidies), than in the US since the US policy instead relies on sticks (employment quotas). However, an impact evaluation by Germundsson et al. (2012) concluded that SE programs work well also in the Swedish framework. These researchers studied a program for employment of individuals with various disabilities (e.g., psychological or psychiatric disability, deafness, dyslexia, ID). Individuals receiving SE-support were hired faster compared with groups not receiving such support.

The present study contributes directly to this literature by being the second study making an impact evaluation of a SE-inspired program in Sweden. However, our main focus, and contribution, is on the potential for such a program, if conducted with pupils in upper secondary school, to save local government money.

\section{The SE-Inspired Program 'Job in Sight'}

The case we study here is a SE-inspired program for pupils with ID in the city of Örebro. The term 'SE inspired' is used because today SE is often synonymous with the Individual Placement and Support (IPS) approach, which is an evidence-based, manual-based program. The program we study followed this approach in most respects, but used internships as an intermediate step before full employment.

The program, called Job in Sight (JIS), was granted 8 million SEK (€0.84 million) ${ }^{3}$ by the European Social Fund (ESF). With cofunding from the project partners Örebro municipality, the National Employment Service, and the National Social Insurance Agency, the total project funding was 20 million SEK (€2.1 million).

The project was part of a large portfolio of projects funded by the ESF part during its program period 2007-2013 trying out innovative methods for improving chances for persons outside the labor market to get a job (ESF 2007, Swedish Government Prop. 2012/13:1). Within the so-called program area 2, a total amount of 4.1 billion SEK (€431.5 million) was granted to 496 projects, one of these being JIS. Unfortunately, although an overarching aim was to learn about how innovative methods work in practice, experimental designs were not used. An overall ex-post evaluation (Szulkin et al., 2013) therefore concluded that lack of comparable control groups made it difficult to assess effect sizes. ${ }^{4}$

The JIS program was conducted during the period October 8, 2009, to January 6, 2013. The target group was all pupils with ID who took part in high-school education in the three upper secondary special schools in Örebro. These pupils were invited to participate in the JIS project. The core of the project was to offer support as well as to 
raise employers' interest and willingness to hire young people with disabilities, with the objective to reach employment in the regular labor market. The JIS staff consisted of personal assistants, advisers, social consultants, and a project manager. ${ }^{5}$

All pupils attending the three programs of the Upper Secondary School for Individuals with Learning Disabilities (USSILD) at the moment (69 pupils, $56 \%$ male) accepted voluntarily to participate in JIS during the project period (Gustafsson, 2013). ${ }^{6}$ They met the personal assistants as soon as possible, staff from the Employment Service at the end of the third year. They were then provided internships at regular work places during the fourth year. Participation in JIS was voluntary, but these internships were compulsory and were selected with an explicit aim that the pupils should be able to proceed to an employment at the same work place. Indeed, immediately after school 44 pupils $(64 \%)$ were given employment, most of them at regular work places with state-funded wage subsidies, and a few (six persons) in sheltered employment (Gustafsson, 2013).

The cost per pupil of this project was 290,000 SEK (€30,527), for 3 years of support. From the perspective of the school administration, this was a substantial resource injection, corresponding to $114 \%$ of the cost of a full school year. ${ }^{7}$

A follow-up type of evaluation based on interviews with the JIS personnel, pupils, and employers was made immediately after the end of the project period (Gustafsson, 2013). It concluded that the main contribution of the project was to develop an approach that has not been used before for supporting transition to the labor market for young people with ID, starting already in school. Normally, pupils leave school and then go the local office of the National Employment Service. A marked contrast to previous routines was therefore the involvement of the National Employment Service already from the third school year, instead of at some time after the pupils have left school. This also affected the education in school by making preparations for work life more targeted toward abilities and knowledge that would be useful at specific work places.

\section{Method}

\section{Procedure/Study Design}

Using a before-after intervention design, an evaluation was performed of the impact of the JIS program on the former USSILD pupils' employment status in November during 4 years, beginning with the graduation year (the school year ends in the first days of June and Statistics Sweden classifies all residents' employment status from statistical records during 1 week in November). The former pupils' employment status was followed with register data from Statistics Sweden.

To account for heterogeneity in the composition of the control and intervention groups, the average treatment effect was assessed in a pooled panel Probit model with individual covariates, with clustered robust standard errors. This was then used to make an economic evaluation of the net internal cost if the program had been fully funded by the municipality itself (i.e., instead of being funded by the ESF and national project partners), in consideration of avoided costs for providing day services for those who did not get an employment. 


\section{Participants/Sample}

Data were collected regarding all individuals enrolled in JIS in the four cohorts 2009/2010, 2010/2011, 2011/2012, 2012/2013 (intervention-group), and all individuals in the four cohorts 2005/2006, 2006/2007, 2007/2008, 2008/2009 (control-group) (See Appendix: Table A).

\section{Measures and Data Sources}

The outcome employment status is based on Statistics Sweden's classification. According to this, the number of persons in work in the country a specific year is defined as the number of persons that worked at least 1 hour per week during the month of November. We therefore use this measure as our outcome variable. ${ }^{8}$ For the control group data, this measure was recorded for the period 2006-2013, and the intervention group from 2010 to 2013.

Individual covariates in the pooled panel Probit model were age (in each year, the individual's outcome is followed), gender, youth unemployment rate (individuals aged 18-24) within the municipality, type of program [two regular national and one national with specialization; the two regular programs are the natural resources management (NRM) program, and the hotel and restaurant ( $\mathrm{H} \& \mathrm{R})$ program; the specialized national program version of the industry and vehicle (I \& V) program]. Both the outcome measure and the data for the covariates were register data collected in the Longitudinal Database for Health Insurance and Labor Studies (LISA) at Statistics Sweden. So, we had a set of panel data that is unbalanced because individuals in different cohorts enter into the data set at different times. The data have a panel structure, so the regression model is estimated with pooled panel Probit. To deal with the possible serial correlation and heteroscedasticity, clustered robust standard errors are reported.

The cost of the program was set equal to the total cost of the JIS project [ 20 million SEK (€2.1 million)]. The calculation of the cost of the business as usual alternative will be described later. The average cost per user of Day-Activity Programs in the City of Örebro was held from Socialstyrelsen (2014).

\section{Results}

\section{Summary Statistics}

A summary of the data is given in Table 1 . The control group contains 49 individuals who were followed 5-8 years. The intervention group has 66 individuals followed from 1 to 4 years. The control group is on average 2 years older, which reflects the longer time period that this group was followed. An important difference between the groups is that the share of pupils differs between which type of program the pupils has elected to participate between the groups, for example, $58 \%$ of the pupils attend the I \& V program in the control group compared with $42 \%$ in the intervention group. Controlling for this difference was therefore a motivation for a pooled panel Probit modelling.

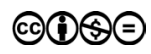


Table I Summary statistics

\begin{tabular}{|c|c|c|c|}
\hline & Mean & Min & Max \\
\hline \multicolumn{4}{|l|}{ Control group } \\
\hline Employment & 0.273 & 0 & I \\
\hline Age & 23.622 & 20 & 29 \\
\hline Male & 0.556 & 0 & । \\
\hline I \&V Program & 0.581 & 0 & । \\
\hline NRM Program & 0.216 & 0 & I \\
\hline H \& R Program & 0.203 & 0 & । \\
\hline No. of individuals & 49 & & \\
\hline No. of observations & 315 & & \\
\hline \multirow[t]{2}{*}{ No. of periods (Years) } & 6.429 & 5 & 8 \\
\hline & Mean & Min & Max \\
\hline \multicolumn{4}{|l|}{ Intervention group } \\
\hline Employment & 0.459 & 0 & । \\
\hline Age & 21.576 & 20 & 24 \\
\hline Male & 0.588 & 0 & । \\
\hline I \&V Program & 0.424 & 0 & । \\
\hline NRM Program & 0.253 & 0 & । \\
\hline H \& R Program & 0.324 & 0 & I \\
\hline No. of individuals & 66 & & \\
\hline No. of observations & 170 & & \\
\hline No. of periods (Years) & 2.576 & । & 4 \\
\hline
\end{tabular}

\section{Before-After Differences}

The differences in the outcome variable between Control and Intervention a number of years after graduation are summarized in Table 2 . There are full observations (four age classes) for the control group during 5 years and partial observations (with three, two, and one age classes, respectively) during 3 more years. There is one full observation (four age classes) and 3 years of partial observations (three, two, and one age class, respectively) for the intervention group.

The share of employed in the control group is increasing from $10 \%$ in the first year to $35 \%$ in the last year when all age classes are observed. The table indicates that the share increases during the first 5 years and then declines from the sixth year. However, the low numbers for the last 3 years come from partial observation of only three, two, and one age classes, respectively.

The comparable shares of the intervention group are much higher. The first year proportion in work was $35 \%$. This is more than the corresponding first year proportion 
Table 2 Numbers and share of persons in work (in November) different years after graduation from USSSLD in Örebro. Control: 2006-2009 graduates, Intervention: 2010-2013 graduates

\section{Control group}

\begin{tabular}{lcccccccc|c}
\hline Year & $T$ & $T+1$ & $T+2$ & $T+3$ & $T+4$ & $T+5$ & $T+6$ & $T+7$ & Class \\
\hline 2006 & 3 & 5 & 5 & 4 & 3 & 3 & 3 & 3 & 6 \\
2007 & 2 & 4 & 2 & 5 & 6 & 4 & 4 & & 20 \\
2008 & 0 & 2 & 3 & 5 & 5 & 6 & & & 14 \\
2009 & 0 & 1 & 2 & 3 & 3 & & & & 9 \\
\hline Total employed & 5 & 12 & 12 & 17 & 17 & 13 & 7 & 3 & 49 \\
\hline Share of employed & 0.102 & 0.245 & 0.245 & 0.347 & 0.347 & 0.265 & 0.143 & 0.061 & \\
Adjusted share of employed & & & & & & 0.325 & 0.269 & 0.500 & \\
\hline
\end{tabular}

\section{Intervention group}

\begin{tabular}{lcccc|l}
\hline Year & $T$ & $T+1$ & $T+2$ & $T+3$ & Class \\
\hline 2010 & 7 & 11 & 8 & 10 & 15 \\
2011 & 9 & 10 & 10 & & 22 \\
2012 & 4 & 6 & & & 15 \\
2013 & 3 & & & & 14 \\
\hline Total employed & 23 & 27 & 18 & 10 & 66 \\
\hline Share of employed & 0.348 & 0.409 & 0.273 & 0.152 \\
Adjusted share of employed & & 0.519 & 0.486 & 0.667 \\
\cline { 1 - 4 } Difference & 0.246 & 0.274 & 0.242 & 0.320 \\
Z & 3.045 & 2.830 & 2.327 & 2.194 \\
\hline
\end{tabular}

Note: $T$ denotes graduation year, $T+$ I next year, and so on.

of the control group but still considerably less than the share $(64 \%)$ reported by Gustafsson (2013) to have been offered employment after school. Thus, it seems that close to half of the first jobs were temporary short-term employments (probably summer jobs). However, the proportion in work rises to about $50 \%$ in year 2 and 3, when we adjust it with the 'class size', and even more for year 4; but for the last year, we only observe one age class.

The table also presents the differences and the corresponding $\mathrm{z}$ values, indicating that the JIS program increased the proportion of each class in employment by at least $24 \%$ persistently over the 4 years for which comparisons are possible. All differences are statistically significant. However, before drawing a definite conclusion, we need to examine whether this could be explained by differences in observable individual characteristics. This has been done with a pooled panel Probit model in the next section. Following that, we report the analysis of the economic significance of the intervention effect. 


\section{Probit Results}

Table 3 summarizes estimated marginal effects of the intervention and the covariates on the probability to be in work from the pooled panel Probit estimations of six different model specifications. Version (5) is the complete model, while, as a check for robustness, some variables have been omitted in the other versions.

The statistically significant coefficients that are age and the dummy variable indicating whether the pupil was in the intervention or not. All other coefficients are insignificant. The results from the complete model (5) show that the probability to be in employment in November increases on average by 5 percentage units by each year of age (during the time span covered by the data). As for the intervention, the results show that the JIS program improved the probability to be in employment with about 30.9. ${ }^{9}$ So neither gender, local youth unemployment rate, program nor that an individual was aged 20 years at graduation did have a significant impact on the employment status in November. These results were robust to omission of the nonsignificant covariates. Model specification (6) with only the two significant variables suggests that the probability of being in employment increases with 3.7 percentage units per year of age and that the intervention increases the probability to be employed with $25.6 \%$.

Table 3 Pooled Panel Probit models for Employment and Intervention Coefficent

\begin{tabular}{|c|c|c|c|c|c|c|}
\hline Employment & $\begin{array}{c}\text { Model } \\
\text { Spec. } \\
\text { I }\end{array}$ & $\begin{array}{c}\text { Model } \\
\text { Spec. } \\
2 \\
\end{array}$ & $\begin{array}{c}\text { Model } \\
\text { Spec. } \\
3 \\
\end{array}$ & $\begin{array}{c}\text { Model } \\
\text { Spec. } \\
4 \\
\end{array}$ & $\begin{array}{c}\text { Model } \\
\text { Spec. } \\
5 \\
\end{array}$ & $\begin{array}{c}\text { Model } \\
\text { Spec. } \\
6 \\
\end{array}$ \\
\hline Age & 0.036 & 0.046 & 0.046 & 0.050 & 0.050 & 0.037 \\
\hline (s.e) & 0.015 & 0.018 & 0.019 & 0.018 & 0.018 & 0.015 \\
\hline Male & 0.101 & 0.097 & 0.124 & 0.098 & 0.124 & \\
\hline (s.e) & 0.075 & 0.074 & 0.091 & 0.074 & 0.091 & \\
\hline Intervention & $0.25 I$ & 0.297 & 0.304 & 0.302 & 0.309 & 0.256 \\
\hline (s.e) & 0.068 & 0.079 & 0.080 & 0.077 & 0.077 & 0.067 \\
\hline Unemployment (I 8-24) & & -0.031 & -0.031 & -0.034 & -0.034 & \\
\hline (s.e) & & 0.024 & 0.024 & 0.022 & 0.022 & \\
\hline NRM Program & & & -0.006 & & -0.005 & \\
\hline (s.e) & & & 0.099 & & 0.099 & \\
\hline H \& R Program & & & -0.067 & & -0.066 & \\
\hline (s.e) & & & 0.104 & & 0.105 & \\
\hline Age 20 at graduation & & & & 0.030 & 0.028 & \\
\hline (s.e) & & & & 0.076 & 0.076 & \\
\hline No. of individuals & 115 & 115 & 115 & 115 & 115 & 115 \\
\hline No. of observations & 485 & 485 & 485 & 485 & 485 & 485 \\
\hline
\end{tabular}

Note: Significant coefficients (5 \%) are marked in bold, Clustered robust standard errors for Probit, clustered on individuals. The table shows the mean marginal probability effects. 


\section{Economic Evaluation}

Based on the average treatment effect reported in the previous section, an economic evaluation of the JIS program, from the point of view of municipality economy, was done. We compare the additional cost of the intervention, which is the difference between the cost of the program and the cost of 'business as usual', with the municipality's benefit, which is the avoided future cost for provision of day-activity services. All costs are calculated under the following assumptions:

1. All costs are expressed as of the price level in 2013.

2. The program cost was set equal to the JIS project cost per pupil, that is, 20 million SEK/69 = 290,000 SEK (€2.1 million/69 = €30,527).$^{10}$

3 . The program replaced some work previously made by liaison teachers. These teachers were assigned 8 hours per pupil and year. Over 4 years and with national average salary level for these kind of teachers, the total avoided cost is estimated to be 7,000 SEK (€737). ${ }^{11}$

4. The average cost per user of day-activity programs in Örebro was assumed to be 122,707 SEK $(€ 12,917)$ (corresponding to the number for 2013, Socialstyrelsen 2014). The effect of an increase of the work share by one percentage unit was assumed to reduce the share of former pupils in day-activity programs by one percentage unit.

5. For the rate of discount, we use both the 3 and $3.5 \%$ rates that are used in the Swedish context. Number of years in day-activity programs: $40 .^{12}$

We calculated the net present value of the intervention and the return on investment period. These results are presented in Table 4. As can be seen, the BCR is 4.987 with a payback (or Return on Investment, ROI) period of 7.5 years ${ }^{13,14}$, when we use the discount rate proposed by the Swedish National Transport Administration. When instead using the discount rate proposed by the TLV, the BCR is 3.094. Thus, the BCR indicates a strongly positive Net Present Value (NPV) and the payback period is within the 10 -year limit used by some Social Investment Funds/Impact Bonds. Important to notice is that the payback period is also below the initial period of activity compensation within the Swedish disability pension scheme. We conclude that the JIS project would have been internally cost saving even if it had to be entirely paid for by the municipality.

Table 4 Net present value, benefit-cost ratio, and payback period for the intervention based on the estimated effect size in model specification 5 , see Table 3

\begin{tabular}{llll}
\hline & $3 \%$ discount rate & $3.5 \%$ discount rate & \\
\hline Net present value & 0.592 mill. SEK & 1.128 mill. SEK & \\
\hline Benefit-cost ratio & 3.09 & 4.99 & \\
\hline Payback period & & & 7.5 years \\
\hline
\end{tabular}




\section{Discussion}

Arvidsson et al. (2015) report that in a sample of former pupils who graduated from USSILD during 2001-2011, only $22 \%$ were employed in 2011. The USSILD is a noncompulsory secondary school available for pupils aged 16-20 who have been considered to have an ID. Forty-seven percent were instead participating in day-activity programs and $24 \%$ were neither engaged in employment, education, or day programs. In this study, we used register data to evaluate the job market effect of a SE-inspired program for pupils with ID in the last years of upper secondary school. We found that it indeed was effective, increasing the share of people in work by 30.9 percentage units. The effect was found to be persistent over the 4 years for which comparisons can be made between the control and intervention groups.

Being the second impact evaluation study of SE in the Swedish context, this study corroborates the finding of the previous study (Germundson et al., 2012) that SE works as well in a wage-subsidy policy framework as in an employment-quotas setting. Also, at least in this context, SE seems to be effective also toward youth in 'transition ages'.

In the economic assessment, we assumed that a former pupil who gets an employment because of the intervention would otherwise be in a day-activity program. However, one-third of the persons who are not in work in the national population are in the category that Arvidsson et al. (2015) call 'elsewhere'. However, the assumption made here can be motivated on two grounds. First, a regression analysis by Arvidsson et al. (2015) shows that former pupils who are in daily activities and in employment were less than the average former pupils characterized by having incomplete grades from USSILD (odds ratio 0.9 and 0.6 , respectively), while former pupils who were 'elsewhere' were characterized more than the average by incomplete grades (odds ratio 1.7). This therefore suggests that persons ending up 'elsewhere' are in general less 'employable' than those ending up in daily activities. Second, even if a young person is 'elsewhere' at a specific moment, this does not mean that this person will not end up in daily activities later. In a forward-looking investment analysis, it would be wrong to use the 'snap-shot' share. Adding these two aspects, the error made by the one-to-one assumption seems to be within the overall error margins of an analysis like this.

An evaluation based on a before-after design is vulnerable to changes of external conditions during the study period. Sweden had during the period 1995-2013 a rather large and steady unemployment rate among young individuals, in spite of overall economic growth. This period was interrupted in 2009 by the international finance crisis. The Swedish economy bounced back to a path of economic growth in 2011. The crisis therefore may have affected to some extent both the control and the intervention group. Inclusion of the local youth unemployment rate to control for this development indicates that the results for the impact of the program are robust to this.

\section{Conclusions}

In several European countries, ${ }^{15}$ both basic education for children and youth with ID and day-activity programs for adults are provided by local governments. ${ }^{16}$ In Sweden, there are such schools at the compulsory primary and lower secondary levels and the 
noncompulsory upper secondary level. This means that measures that increase the likelihood for transition to employment before, during, and after pupils leave school could possibly be regarded as a 'social investments', that is, the cost of such measures could pay off from avoided future expenditure for daily programs (wage subsidies for those who get an employment are paid over the national state budget and not by the municipality). However, in most municipalities, resources for USSILD and day-activity programs are strictly separated in different budgets that are managed by separate administrations and political boards, so there is normally no explicit consideration of a linkage between these cost items. It can therefore be conjectured that municipalities underinvest in this kind of support.

Since 2010, approximately 70 of the 290 Swedish municipalities, including the three largest cities, Stockholm, Göteborg, and Malmö, have established 'social investment funds' for funding of such 'investment' measures that are expected to reduce future expenditure needs (Bokström et al., 2014; Hultkrantz, 2014, 2015; Hultkrantz \& Vimefall, 2017). Some of these funds require that grants that are awarded for such measures will subsequently be returned (through internal accounting transfers) when the expected cost savings accrue. For instance, the social investment fund in the city of Norrköping, which was the first municipality to set up such a fund, requires full repayment within 10 years (Källbom, 2014). Applicants for funding in this city need to present an economic investment assessment that demonstrates that the measure can be expected to be cost saving (i.e., that expected internal cost reductions cover the initial expenditure). There is no similar requirement to show net benefits in a societal perspective. Thus, priority is given to 'business case' investments from which returns are held within the municipality's own economy, although probably some qualitative assessment is made of the wider societal welfare effects.

The main finding of the economic evaluation is that even though the SE-inspired program was very expensive if seen from the point of view of the school administration, costing more than an additional school year, it could lead to reduced expenditure for the municipality as a whole. The result of the economic assessment of the JIS program that was made here implies that if it were considered as a 'social investment' prospect, it would indeed meet such a payback requirement.

A possible explanation for the effectiveness of the JIS program that we have found may be that it started already in school, in contrast to the conventional support provided by the national employment service to young adults who register as unemployed at the local office sometime after graduation from the USSILD. Combined with the observation that there are very small chances of ever getting a job at a regular work-place after having become a daily-activities client, this suggests that a better coordination between the education system and labor-market services could enhance the performance of the job opportunities policy for people with ID in Sweden.

\section{Acknowledgement}

This research has been funded by grants from Jan Wallander's and Tom Hedelius' Foundation, Tore Browald's Foundation, and the City of Örebro. We thank Johanna Gustafsson for sharing her knowledge about the 'Job in Sight' program. 


\section{References}

Antonson, S. (2003). Stödets betydelse: supported employment: $i$ kampen för arbete och att bryta utsatthet [The Importance of Aid: Supported Employment: In Struggle for Work and Breaking Exclusion]. Örebro universitet.

Arvidsson, J., Widén, S., and Tideman, M. (2015). Post-school options for young adults with intellectual disabilities in Sweden. Research and Practice in Intellectual and Developmental Disabilities, 2(2): 180-193. doi: http://dx.doi.org/10.1080/23297018.2015.1028090.

Asp, L. (2012). Jobb i sikte-metoden - Ett nytt sätt att samverka - Från Särskola till Arbetsliv [The Job in Sight Method - A New Way to Cooperate - From Special Needs School to Employment]. The Swedish ESF Council. Retrieved from: http://www.esf.se/ PageFiles/2201440/jis\%20metoden \%202\%20april\%202012.pdf.

Beadle-Brown, J., Mansell, J., García-Ibañez, J., Magallanes, T., Novell, R., Poole, M., Salvador-Carulla L., Molleman C., Van Hove G., Vlaskamp C., and Aselmeier, L. (2003). Intellectual disability in Europe: overview. European Intellectual Disability Research Network (Eds.), Intellectual disability in Europe. Working papers, 1-11.

Beyer, S. and Kilsby, M. (1998). Financial costs and benefits of two supported employment agencies in Wales. Journal of Applied Research in Intellectual Disabilities, 11(4), 303319. doi: http://dx.doi.org/10.1111/j.1468-3148.1998.tb00039.x.

Blitz, C. L. and Mechanic, D. (2006). Facilitators and barriers to employment among individuals with psychiatric disabilities: A job coach perspective. Work, 26(4): 407-419.

Bokström, T., Lindencrona, F. and Wieselgren, M. (2014). Sociala investeringar - från dröm till verklighet [Social Investments - from dream to reality] Socialmedicinsk tidskrift, 91(3): 245-252.

Bond, G. R., Drake, R. E. and Becker, D. R. (2008). An update on randomized controlled trials of evidence-based supported employment. Psychiatric rehabilitation journal, 31(4): 280-290. doi: http://dx.doi.org/10.2975/31.4.2008.280.290.

Burke-Miller, J., Razzano, L. A., Grey, D. D., Blyler, C. R. and Cook, J. A. (2012). Supported employment outcomes for transition age youth and young adults. Psychiatric rehabilitation journal, 35(3): 171-179. doi: http://dx.doi.org/10.2975/35.3.2012.171.179.

Cimera, R. E. (1998). Are individuals with severe mental retardation and multiple disabilities cost-efficient to serve via supported employment programs?. Mental Retardation, 36(4): 280-292. doi: http://dx.doi.org/10.1352/0047-6765(1998)036\%3C0280:AIWSMR\%3E2.0.CO;2.

Cimera, R. E. (2010a). National cost efficiency of supported employees with intellectual disabilities: 2002 to 2007. American Journal on Intellectual and Developmental Disabilities, 115(1): 19-29. doi: http://dx.doi.org/10.1352/1944-7558-115.1.19.

Cimera, R. E. (2010b). Can Community-Based High School Transition Programs Improve the Cost-Efficiency of Supported Employment?. Career Development for Exceptional Individuals, 33(1): 4-12. doi: http://dx.doi.org/10.1177/0885728809346959.

Cimera, R. E. (2012). The economics of supported employment: What new data tell us. Journal of Vocational Rehabilitation, 37(2): 109-117. doi: http://dx.doi.org/10.3233/JVR2012-0604.

Clark, R. E., Dain, B. J., Xie, H., Becker, D. R. and Drake, R. E. (1998). The economic benefits of supported employment for persons with mental illness. The journal of mental health policy and economics, 1(2), 63-71. doi: http://dx.doi.org/10.1002/(SICI)1099-176X(199 807)1:2\%3C63::AID-MHP8\%3E3.0.CO;2-2.

Clark, R. E., Xie, H., Becker, D. R. and Drake, R. E. (1998). Benefits and costs of supported employment from three perspectives. The journal of behavioral health services and research, 25(1): 22-34. doi: http://dx.doi.org/10.1007/BF02287497. 
Conley, R. W., Rusch, F. R., McCaughrin, W. B. and Tines, J. (1989). Benefits and costs of supported employment: An analysis of the Illinois supported employment project. Journal of Applied Behavior Analysis, 22(4): 441-447. doi: http://dx.doi.org/10.1901/ jaba.1989.22-441.

Drake, R. E., and Bond, G. R. (2008). The future of supported employment for people with severe mental illness. Psychiatric rehabilitation journal, 31(4), 367-376. doi: http://dx. doi.org/10.2975/31.4.2008.367.376.

de Urríes, F. B., Verdugo, M. A., Jenaro, C., Crespo, M. and Caballo, C. (2005). Supported employment and job outcomes. Typicalness and other related variables. Work, 25(3): 221-229.

Dowler, D. L. and Walls, R. T. (2014). A review of supported employment services for people with disabilities: Competitive employment, earnings, and service costs. Journal of Rehabilitation, 80(1): 11-21.

Svenska ESF-rådet (2007) Projektbanken 2007-2013 [The Project Bank 2007 - 2013]. [The Swedish ESF Council] [ESF] Accesed 2016-10-11, from http://www.esf.se/sv/Resultat/ Projektbanken/.

Germundsson, P., Gustafsson, J., Lind, M. and Danermark, B. (2012). Disability and supported employment: impact on employment, income, and allowances. International Journal of Rehabilitation Research, 35(3), 263-269. doi: http://dx.doi.org/10.1097/ MRR.0b013e3283544d3c.

Greve, B. (2009). The labour market situation of disabled people in European countries and implementation of employment policies: a summary of evidence from country reports and research studies. Academic Network of European Disability Experts (ANED).

Gustafsson, J., Peralta, J. P. and Danermark, B. (2013a). The employer's perspective on Supported employment for people with disabilities: Successful approaches of Supported employment organizations. Journal of Vocational rehabilitation, 38(2): 99-111. doi: http://dx.doi.org/10.3233/JVR-130624.

Gustafsson, J., Peralta, J. P. and Danermark, B. (2013b). The employer's perspective: employment of people with disabilities in wage subsidized employments. Scandinavian Journal of Disability Research, 16(3), 249-266. doi: http://dx.doi.org/10.1080/15017419.2013 .785976 .

Gustafsson, J., Peralta, J. P. and Danermark, B. (2015). Being a Worker and Becoming a Co-Worker. How can supported employment provide better opportunities for social inclusion in working life for people with disabilities?, In Gustafsson J. (2015) Supported Employment i en svensk kontext. (Doctoral Dissortation, Studies from the Swedish Institute for Disability Research, 59). Örebro: Örebro University.

Gustafsson, J. (2013). Jobb i sikte - Utvärdering 2009 - 2013 [Job in Sight - Evaluation 2009_ 2013]. The Swedish ESF Council. Retrieved from: http://www.esf.se/PageFiles/2201440/ slututv \% C3\%A4rdering\%20JIS\%20final\%20version2.pdf.

Gustafsson, J. (2014). Supported employment i en svensk kontext: förutsättningar när personer med funktionsnedsättning når, fär och behåller ett arbete [Supported Employment in a Swedish Context: Circumstances when Individuals with Disabilities Reach, Get and Retain Employment].(Doctoral Dissortation, Studies from the Swedish Institute for Disability Research, 59). Örebro: Örebro University. Retrieved from: http://oru.diva-portal. org/smash/get/diva2:706615/FULLTEXT03.pdf.

Heslin, M., Howard, L., Leese, M., McCrone, P. A. U. L., Rice, C., Jarrett, M., Spokes, T., Huxley, P. and Thornicroft, G. (2011). Randomized controlled trial of supported employment in England: 2 year follow-up of the Supported Work and Needs (SWAN) study. World Psychiatry, 10(2): 132-137. doi: http://dx.doi.org/10.1002/j.2051-5545.2011. tb00035.x. 
Hill, M. L., Banks, P. D., Handrich, R. R., Wehman, P. H., Hill, J. W. and Shafer, M. S. (1987). Benefit-cost analysis of supported competitive employment for persons with mental retardation. Research in Developmental Disabilities, 8(1): 71-89. doi: http://dx.doi.org/ 10.1016/0891-4222(87)90041-2.

Hill, M. and Wehman, P. (1983). Cost benefit analysis of placing moderately and severely handicapped individuals into competitive employment. Research and Practice for Persons with Severe Disabilities, 8(1): 30-38. doi: http://dx.doi.org/10.1177/154079698300800104.

Hoffmann, H., Jäckel, D., Glauser, S., Mueser, K. T. and Kupper, Z. (2014). Long-term effectiveness of supported employment: 5-year follow-up of a randomized controlled trial. American Journal of Psychiatry, 171(11): 1183-1190. doi: http://dx.doi.org/10.1176/ appi.ajp.2014.13070857.

Hope, J. and Fraser, R. (1997). Beyond budgeting ... breaking through the barrier to the 'third wave'. Management Accounting, 75: 20-23.

Hope, J. and Fraser, R. (2003). Beyond budgeting: How Managers Can Break Free from the Annual Performance Trap. Boston: Harvard Business School Press.

Hultkrantz, L. (2014). Sociala investeringsfonder-ett nytt sätt att styra kommunalt förändringsarbete? [Social Investment Funds - a New Way to Steer Municipality Work of Change?]. Socialmedicinsk tidskrift, 91(3): 223-231.

Hultkrantz, L. (2015). Sociala investeringsfonder i Sverige [Social Investment Funds in Sweden]. Stockholm: SNS Förlag.

Hultkrantz, L. and Vimefall, E. (2017) Social Investment Funds in Sweden: Status and Design Issues. Scandinavian Journal of Public Administration (in press).

Knapp, M., Patel, A., Curran, C., Latimer, E., Catty, J., Becker, T., Drake, R.E., Fioritti, A., Kilian, R., Lauber, C. and Rössler, W. (2013). Supported employment: Cost-effectiveness across six European sites. World Psychiatry, 12(1): 60-68. doi: http://dx.doi.org/10.1002/ wps. 20017.

King, R., Waghorn, G., Lloyd, C., McLeod, P., McMah, T. and Leong, C. (2006). Enhancing employment services for people with severe mental illness: the challenge of the Australian service environment. Australian and New Zealand Journal of Psychiatry, 40(5): 471-477. doi: http://dx.doi.org/10.1080/j.1440-1614.2006.01824.x.

Källbom, L. (2014) Norrköpings sociala investeringsfond [The Social Investment Fund of Norrköping]. Socialmedicinsk tidskrift, 91(3): 253-260.

Latimer, E. A. (2001). Economic impacts of supported employment for persons with severe mental illness. The Canadian Journal of Psychiatry, 46(6): 496-505. doi: http://dx.doi. org/10.1177/070674370104600603.

Mak, D. C., Tsang, H. W. and Cheung, L. C. (2006). Job termination among individuals with severe mental illness participating in a supported employment program. Psychiatry, 69(3): 239-248. doi: http://dx.doi.org/10.1521/psyc.2006.69.3.239.

Marshall, T., Goldberg, R. W., Braude, L., Dougherty, R. H., Daniels, A. S., Ghose, S. S., George, P. and Delphin-Rittmon, M. E. (2014). Supported employment: assessing the evidence. Psychiatric Services, 65(1): 16-23. doi: http://dx.doi.org/10.1176/appi.ps.201300262.

Mavranezouli, I., Megnin-Viggars, O., Cheema, N., Howlin, P., Baron-Cohen, S. and Pilling, S. (2014). The cost-effectiveness of supported employment for adults with autism in the United Kingdom. Autism, 18: 975-984. doi: http://dx.doi.org/10.1177/1362361313505720.

Swedish Government Prop. 2012/13:1. Budgetpropositionen för 2013 - Förslag till statens budget för 2013, finansplan och skattefrågor. [Budget Bill for 2013 - Proposal for Government Budget for 2013, Financial Plan and Tax Issues]. Retrieved from: http://www. regeringen.se/49bb18/contentassets/5d29304417da4cd8ae098aeb0aeef057/forslag-tillstatens-budget-for-2013-finansplan-och-skattefragor-kapitel-1-12.

Reme, S. E., Grasdal, A. L., Løvvik, C., Lie, S. A. and Øverland, S. (2015). Work-focused cognitive-behavioural therapy and individual job support to increase work participation 
in common mental disorders: a randomised controlled multicentre trial. Occupational and environmental medicine, 72(10): 745-752. doi: http://dx.doi.org/10.1136/oemed2014-102700.

Rogers, E. S., Sciarappa, K., MacDonald-Wilson, K. and Danley, K. (1995). A benefit-cost analysis of a supported employment model for persons with psychiatric disabilities. Evaluation and Program Planning, 18(2): 105-115. doi: http://dx.doi.org/10.1016/01497189(95)00002-S.

Rose, J., Saunders, K., Hensel, E. and Kroese, B. S. (2005). Factors affecting the likelihood that people with intellectual disabilities will gain employment. Journal of Intellectual Disabilities, 9(1): 9-23. doi: http://dx.doi.org/10.1177/1744629505049725.

Socialstyrelsen, (2013). Utvärdering av försöksverksamheter i kommuner - Individual Placement and Support, individanpassat stöd till arbete för personer med psykisk funktionsnedsättning [Evaluation of Trial Activities in Municipalities - Indvidual Placement and Support, Personalized Support to Employment for Individuals with Mental Disabilities]. [The National Board of Health and Welfare].

Socialstyrelsen (2014). Personer med funktionsnedsättning - insatser enligt LSS år 2013 [Individuals with Disabilities - Recieving Services under LSS in 2013]. [The National Board of Health and Welfare].

Szulkin, R., Nekby, L., Bygren, M., Lindblom, C., Russell-Jonsson, K., Bengtsson, R. and Normark, E. (2013). På jakt efter framgångsrik arbetslivsintegrering [In Search of Successful Work Life Integration]. Institutet för Framtidsstudier, Stockholm.

Tirole, J. (1988). The theory of industrial organization. MIT press.

Washington State Institute for Public Policy (2015). Benefit-cost technical documentation. [WSIPP].

Wehman, P., Inge, K. J., Revell, W. G. and Brooke, V. A. (2007). Supported employment and workplace supports: Overview and background. Real work for real pay: Inclusive employment for people with disabilities. Baltimore: Paul H. Brookes, 117-138.

Westerholm, P., Lundberg, I., Anderzén, I., Lytsy, P., Fredriksson, K., Rehfisch, P., Helgesson, M., Gustafsson, M. and Zaar, K. (2013). Aktivitetsersättning-en väg till arbete?: En systematisk litteraturöversikt [Activity Compensation - a Way to Employment?: A Systematic Literature Review]. Social Insurance Report 2013:3, Försäkringskassan, Stockholm.

\section{Notes}

${ }^{1}$ Intellectual disability is defined by the American Association on Intellectual and Developmental Disabilities (www.aaidd.org) as a disability characterized by significant limitations in both intellectual functioning and in adaptive behavior, which covers many everyday social and practical skills. This disability originates before the age of 18. In Sweden, Special Upper Secondary Schools for 'learning disabilities' (direct translation) are provided for pupils diagnosed according to the ICD-10 manual, with IQ below 70 as the main requirement. 'Learning disabilities' may have a different meaning in the US, so therefore we use the American term here.

${ }^{2}$ Based on interviews with employers and employees, Gustafsson et al. (2013a,b, 2015) give an account of how these information aspects were perceived and mitigated by a Swedish Supported Employment program for persons with ID.

${ }^{3}$ Exchange rate $€ 1=9.5$ SEK.

${ }^{4}$ On average, performance of the granted projects was inferior to results from conventional support for unemployed persons (provided by the National Employment Service). However, supported clients belonged to categories with more difficult problems than the average unemployed person. 
${ }^{5}$ For a detailed description (in Swedish) of the project, see Asp (2012).

${ }^{6}$ Three of them, however, dropped out at an early stage. No explanations for this have been recorded. These three were not included in the Intervention group.

${ }^{7}$ The average cost per pupil 2010 in the three USSILD schools was 255,300 SEK $(€ 26,873)$ (Skolverket, SIRIS).

${ }^{8}$ This is the only available measure of employment status that covers all individuals of the whole population. More frequent employment statistics are collected in the Labor Force Survey, based on telephone interviews of a representative sample of the population. The classification was changed in 2011, but it has been possible to use the old classification for the whole period of our study. Of those individuals who were registered as being employed in a year, $95 \%$ had an annual earned income the same year above $50 \%$ of the average income, thus they worked more than a few hours per week.

${ }^{9}$ Interaction terms (in model versions not reported here) with Male and Age, respectively, were not significant. The specification interacting Age and Intervention is difficult to interpret since the age span of the intervention group is shorter than that of the control group. For the later, the intervention term will also become insignificant. No other interaction terms for intervention and program generate any significant coefficients.

${ }^{10}$ We divide with 69 pupils since the initial project budget was scaled for this number of pupils.

$11(32 / 170)$ times gross salary 39,000 SEK/month (€4,105). Personal communication with Lennart Asp, April 2016.

12 The rate of discount is the rate used by the Dental and Pharmaceutical Benefits Agency $(3 \%)(T L V)$ and the National Transport Administration (3.5\%) (Trafikverket), the latter is often used by other governmental agencies in Sweden as well. There is no information available on how long people stay in day-activity programs. However, very few leave these programs for transition to work, so they can be regarded to have 'black hole properties'.

${ }_{13}$ When restricting the time of interest to a maximum of 4 years, the intervention effect increases to $33.3 \%$. This gives a ROI of 6.9 years and a BCR of 5.379 .

14 The results from a Linear Probability Model are similar with a ROI period of 7.4 and BCR of 5.005 , since the intervention effect is $31 \%$.

${ }^{15}$ For an overview see Beadle-Brown et al. (2003).

${ }_{16}$ Municipalities are obliged to provide such day programs for persons with intellectual disabilities according to Law (1993: 387) concerning Support and Service for certain disabled (LSS). 


\section{Appendix}

Table A Distribution of Individuals over time, Group, and Cohort

\begin{tabular}{|c|c|c|c|c|c|c|c|c|}
\hline & 2006 & 2007 & 2008 & 2009 & 2010 & 2011 & 2012 & 2013 \\
\hline \multicolumn{9}{|c|}{ Control Group } \\
\hline 2006 & 6 & 6 & 6 & 6 & 6 & 6 & 6 & 6 \\
\hline 2007 & & 20 & 20 & 20 & 20 & 20 & 20 & 20 \\
\hline 2008 & & & 14 & 14 & 13 & 14 & 14 & 13 \\
\hline 2009 & & & & 9 & 9 & 9 & 9 & 9 \\
\hline \multicolumn{9}{|c|}{ Intervention Group } \\
\hline 2010 & & & & & 15 & 15 & 15 & 15 \\
\hline 2011 & & & & & & 22 & 22 & 22 \\
\hline 2012 & & & & & & & 15 & 15 \\
\hline 2013 & & & & & & & & 14 \\
\hline
\end{tabular}

Note: One person in the 2008 cohort is missing in 2010 and 2013. Since the register covers all Swedish residents, this must be because of (temporary) foreign residency. 